\title{
Bioavailable Testosterone Measurement
}

National Cancer Institute

\section{Source}

National Cancer Institute. Bioavailable Testosterone Measurement. NCI Thesaurus.

Code $C 117860$.

The determination of the amount of bioavailable testosterone present in a sample. 